\title{
Kadar Antioksidan Rendah Meningkatkan Risiko Hemolisis pada Sepsis Neonatus
}

\section{Low Antioxidant Levels Increase the Risk of Hemolysis in Neonatal Sepsis}

\author{
Kamilah Budhi $R^{1}$, Agustinus Soemantri ${ }^{1}$, Asril Aminullah ${ }^{2}$, Suhartono ${ }^{3}$ \\ ${ }^{1}$ Departemen Pediatri Fakultas Kedokteran Universitas Diponegoro/Rumah Sakit Umum Pusat Dr. Kariadi Semarang \\ ${ }^{2}$ Departemen Pediatri Fakultas Kedokteran Universitas Indonesia/Rumah Sakit Dr. Ciptomangunkusuma \\ Jakarta \\ ${ }^{3}$ Fakultas Kesehatan Masyarakat Universitas Diponegoro Semarang
}

\begin{abstract}
ABSTRAK
Hemolisis pada neonatus sepsis terjadi akibat aktivasi komplemen yang dipicu oleh reaksi inflamasi sebagai respons terhadap invasi mikroba. Penyebab lain meliputi: proses fisiologis, kelainan eritrosit kongenital, proses imun, stres oksidatif, obat dan enzim hemolisin. Penelitian ini bertujuan untuk membuktikan hubungan antara kadar antioksidan dengan kejadian hemolisis pada neonatus sepsis. Penelitian dilakukan dengan desain observasional prospektif, nested case-control pada 94 neonatus sepsis yang terdiri 47 kelompok kasus (hemolisis positif) dan 47 kelompok kontrol (hemolisis negatif). Hemolisis ditegakkan dengan kriteria indeks retikulosit $>3$ pada hari ke 1 dan hari ke 3 . Variabel yang diukur meliputi: antioksidan (GPx, vitamin E, vitamin C) dan oksidan (MDA), hemolisin. Pemeriksaan kadar MDA, GPx dengan metode spektrofotometri, vitamin C metode colorimetric assay, vitamin E metode ELISA, hemolisin dengan media agar darah. Data dianalisis dengan Chi-square, uji t tidak berpasangan, Mantel-Haenszel dilanjutkan regresi logistik. Hasil penelitian menunjukkan kadar GPx rendah $(75 \mu / \mathrm{gHb})$, vitamin $\mathrm{E}$ rendah $((<17,8 \mu \mathrm{g} / \mathrm{mL})$ merupakan faktor risiko signifikan terjadinya hemolisis dengan OR berturut-turut $6,14,3,12$. Kadar antioksidan rendah (GPx dan vitamin E) merupakan prediktor kuat terjadinya hemolisis pada neonatus sepsis.
\end{abstract}

Kata Kunci: Antioksidan, hemolisis, neonatus sepsis

\begin{abstract}
Hemolysis in neonatal sepsis is caused by complement activation triggered by inflammatory reactions in response to microbial invasion. Other causes include: physiological conditions, congenital erythrocyte disorders, immunological processes, oxidative stress, drugs and hemolysin. The aim of this study was to determine the correlation between antioxidant level and hemolysis in neonatal sepsis. Prospective observational study with a nested case-control was done in 94 neonatal sepsis, consisted of 47 cases (positive hemolysis) and 47 controls (negative hemolysis). Hemolysis was positive if reticulocyte index $>3$ on day 1 and 3. Risk factors examined were: antioxidant (GPx, vitamin E, vitamin C) and oxidant (MDA), hemolysin. MDA and GPx were measured using spectrophotometry, vitamin C by colorimetric assay, vitamin E by ELISA, and hemolysin by blood agar medium. Data were analyzed using Chi-square, unpaired t-test, Mantel-Haenszel and logistic regression. The results showed low GPx level $(75 \mu / \mathrm{gHb})$ and low vitamin E level $(<17,8 \mu \mathrm{g} / \mathrm{mL})$ were significant risk factors for hemolysis with OR 6,14 and 3,12 respectively. Low antioxidant level (GPx and vitamin E) are strong predictors for hemolysis in neonatal sepsis.
\end{abstract}

Keywords: Antioxidant, hemolysis, neonatal sepsis

Jurnal Kedokteran Brawijaya, Vol. 26, No. 3 Februari 2011; Korespondensi: Kamilah Budhi R. Departemen Pediatri Fakultas Kedokteran Universitas Diponegoro Semarang, Jl. H. Prof. Sudarto, SH, Tembalang, Semarang, Tel. (024) 7460053, 7460055 Email: kamilabudhi@yahoo.co.id 


\section{PENDAHULUAN}

Sepsis adalah sindrom respons inflamasi sistemik (systemic inflammatory response syndrome/SIRS) yang disertai manifestasi klinis infeksi (1). Di Indonesia kematian neonatal menduduki $37 \%$ kematian bayi yang disebabkan oleh distres respirasi, sepsis, hipotermi, bayi berat lahir rendah (BBLR), penyakit metabolik dan cacat bawaan (2).

Peningkatan spesies oksigen reaktif (SOR) atau oksidan kuat akan terjadi pada kondisi sepsis khususnya oleh leukosit polimorfonuklear (PMN) sebagai respons terhadap endotoksin kuman. Peningkatan SOR yang melebihi kapasitas pertahanan antioksidan akan terjadi stres oksidatif atau peroksidasi lipid, berakibat kerusakan organ yang rentan seperti lipid membran sel, kerusakan membran eritrosit berdampak memendeknya umur eritrosit, menurunnya fragilitas ataupun secara langsung merusak membran eritrosit sehingga terjadi hemolisis (3).

Peningkatan aktivitas antioksidan merupakan respons kompensasi terhadap adanya stres oksidatif. Glutathione peroxydase (GPx), vitamin E dan vitamin C saling berinteraksi merupakan jaringan antioksidan untuk melawan stres oksidatif melalui peroksidasi lipid sehingga menjaga keutuhan membran eritrosit dan mencegah hemolisis $(4,5)$. Antioksidan GPx, penting untuk mengkatalisis reaksi $2 \mathrm{GSH}+\mathrm{H}_{2} \mathrm{O}_{2}$ GSSG $+2 \mathrm{H}_{2} \mathrm{O}$, GSSG (glutation teroksidasi) direduksi menjadi GSH (glutation tereduksi) oleh niacin adenin dinucleotide phosphat (NADPH) yang dihasilkan oleh glucose 6 phosphate dehydrogenase (G6PD). GSH berperan penting dalam mempertahankan struktur normal eritrosit (5). Vitamin E bekerja sinergis dengan selenium yang terdapat dalam GPx sehingga melindungi membran eritrosit terhadap oksidan. Vitamin C mempertahankan banyak kofaktor logam dalam keadaan tereduksi serta melindungi biomembran terhadap kerusakan oksidatif (4). Studi akhir menyokong hipotesis bahwa fungsi mikrovaskuler pada sepsis diperbaiki oleh pemberian vitamin C parenteral sebagai terapi ajuvan. Perlu studi berikutnya untuk menentukan keamanan dan kemanjuran asam askorbat pada pasien sepsis(6). Karim melaporkan, $\alpha$-tocopherol menurunkan kejadian stres oksidatif pada bayi asfiksia (7). Selenium sebagai gugus prostetik GPx, dalam diet (selenoprotein) meregulasi balans redoks, meningkatkan fungsi imun dan memediasi resistensi terhadap infeksi virus (8).

Peroksidasi lipid, mengakibatkan terputusnya rantai asam lemak menjadi berbagai senyawa toksik antara lain berbagai macam aldehida seperti malondialdehyde (MDA), 9-hidroksi-nonenal serta bermacam-macam hidrokarbon seperti etana $(\mathrm{C} 2 \mathrm{H} 6)$ dan pentana $(\mathrm{C} 5 \mathrm{H} 12)$ sehingga menyebabkan kerusakan parah membran sel berupa peningkatan permeabilitas membran hingga lisis sel. MDA digunakan sebagai biomarker biologis peroksidasi lipid untuk menilai stres oksidatif (peningkatan oksidan). Proses hemolisis merupakan petunjuk adanya peningkatan stres oksidatif, juga petunjuk meningkatnya kadar bilirubin (3). Produksi oksigen radikal bebas yang tinggi ditunjukkan oleh peningkatan kadar MDA dan penurunan kadar GSH, vitamin C, vitamin E dan aktivitas katalase, mendukung adanya stres oksidatif pada neonatus yang mengalami hiperbilirubinemia (5).
Hemolisis, suatu destruksi eritrosit, dengan etiologi luas meliputi proses imun, infeksi, defek membran dan defek enzim eritrosit (9). Hemolisis fisiologis terjadi pada neonatus disebabkan pendeknya umur eritrosit (60-80 hari), menyebabkan peningkatan bilirubin indirek yang kadarnya mencapai puncak 5-6 mg/dL pada hari ke 3-4, menurun setelah hari ke 7 (10). Kadar bilirubin indirek yang $>10 \mathrm{mg} / \mathrm{dL}$, perlu diwaspadai suatu kondisi patologis yang disebabkan diantaranya oleh infeksi (11).

Invasi mikroba, memberi respons inflamasi yang memproduksi sitokin proinflamasi, mengaktivasi komplemen, C5-C9 membentuk membrane attack complex (MAC), menyebabkan cedera membran sel yang berakibat lisis sel (12). Hemolisis yang dipicu obat, terjadi karena reaksi hipersensitivitas tipe II atau III, kerusakan sel terjadi akibat sitolisis oleh komplemen. Contoh obat pada tipe ini di antaranya adalah penisilin dan sefalosporin (13). Enzim hemolisin, diproduksi oleh beberapa bakteri patogen yaitu bakteri gram negatif diantaranya Escherichia coli, Pseudomonas aeroginosa, Serratia sp., Proteus sp. dan gram positif diantaranya Streptococcus sp., Staphylococcus aureus, Listeria sp., dapat menyebabkan lisis eritrosit (14).

Penulisan dan penelitian tentang kejadian hemolisis pada neonatus sepsis pada penelusuran pustaka jarang dijumpai. Penelitian pendahuluan di perawatan bayi risiko tinggi (PBRT) RSUP Dr. Kariadi Semarang 2006, menemukan angka kejadian hemolisis pada neonatus sepsis yang diperiksa dengan metode pembacaan sediaan apus darah tepi, adalah 47,6\% (15). Tujuan penelitian ini adalah untuk membuktikan hubungan antara kadar antioksidan dengan kejadian hemolisis pada neonatus sepsis.

\section{METODE}

Penelitian dilakukan dengan desain nested case-control, di RSUP Dr. Kariadi Semarang tahun 2009. Subjek dipilih secara consecutive sampling dengan kriteria inklusi: menderita sepsis, bayi cukup bulan (BCB), berat lahir $\geq$ 2500 gr dan kriteria eksklusi: menderita defisiensi G6PD, menderita gangguan eritrosit heriditer, tes Coombs positif dan mendapat transfusi darah. Diagnosis sepsis ditegakkan dengan kriteria SIRS (1 atau lebih), gejala klinis, laboratorium, atau penunjang lain dengan atau tanpa adanya hasil kultur darah (1).

Desain ini menelaah hubungan antara faktor risiko, yaitu oksidan (MDA) dan antioksidan (GPx, vitamin C, vitamin E) sebagai variabel bebas dengan efek (kejadian hemolisis) sebagai variabel terikat (16) dan enzim hemolisin dianggap sebagai variabel perancu. Pengamatan secara kohort, dilakukan dengan pemeriksaan kejadian hemolisis hari ke 1 dan diulang hari ke 3 untuk melihat kondisi hemolisis dengan bertambah lamanya paparan faktor risiko. Pengambilan darah untuk faktor risiko (MDA, GPx, vitamin $\mathrm{E}$, vitamin $\mathrm{C}$, hemolisin) dilakukan pada hari 1 , disimpan untuk dianalisis terhadap kelompok kasus dan kelompok kontrol subjek penelitian pada hari ke 3 . Hemolisis karena obat tidak diteliti sebab kedua kelompok diberi perlakuan sama yaitu terapi penisilin atau sefalosporin. Aktivasi komplemen merupakan mekanisme terjadinya hemolisis sebagai respons terhadap invasi mikroba dalam penelitian ini tidak diteliti.

Sebanyak 110 neonatus sepsis, pada pemeriksaan hari 1 
didapati 54 neonatus hemolisis positif dan 56 neonatus hemolisis negatif sehingga angka kejadian hemolisis pada penelitian ini $49 \%$. Pada hari ke 3 , pemeriksaan hemolisis diulang sehingga terjadi perubahan kejadian hemolisis. Ditetapkan 94 subjek penelitian yang akan diteliti, terdiri 47 neonatus sepsis hemolisis positif sebagai kelompok kasus dan 47 neonatus sepsis hemolisis negatif sebagai kelompok kontrol. Kejadian hemolisis hari ke 1 dengan rerata kadar bilirubin indirek $6,63 \mathrm{mg} / \mathrm{dL} \pm 1,70$ atau $<10$ $\mathrm{mg} / \mathrm{dL}$, ini berarti bahwa hemolisis diakibatkan oleh proses fisiologis atau hemolisis fisiologis (11). Pemeriksaan kadar GPx dan MDA (mengukur kadar thio barbituric acid reactive substance/TBARS) dengan spektofotometri, vitamin C dengan colorimetric assay, vitamin E dengan ELISA di labotratorium Bioteknologi Universitas Gajahmada Yogyakarta dan hemolisin dengan kultur darah media agar darah di laboratorium RSUP Dr.Kariadi Semarang. Diagnosis hemolisis ditegakkan dengan metode Indeks Retikulosit, dengan rumus:

$\%$ retikulosit $\times \frac{\text { Observasi.Ht }}{\text { normal.Ht }} \times \frac{1}{u}$. (u= faktor maturasi).

Dinyatakan hemolisis, bila IR >3 (9) dan peningkatan bilirubin (indirek) $>5 \mathrm{mg} \%$. Untuk rujukan nilai normal variabel, dilakukan penelitian pendahuluan terhadap bayi sehat bangsa Indonesia dengan hasil, rerata kadar: hematokrit $=49 \%, M D A=2,90 \mathrm{ng} / \mathrm{mL}, \mathrm{GPx}=75 \mu / \mathrm{gHb}$, vitamin $\mathrm{C}=7 \mu \mathrm{g} / \mathrm{mL}$, vitamin $\mathrm{E}=22 \mu \mathrm{g} / \mathrm{mL}$ (17), yang dipakai untuk penentuan cut off point (COP) pada analisis statistik. Untuk vitamin E, karena kadar vitamin E pada semua subyek penelitian dibawah normal maka untuk keperluan analisis digunakan COP nilai median yaitu $17,8 \mu \mathrm{g} / \mathrm{mL}$ (18).

Analisis data meliputi analisis deskriptif dan uji hipotesis. Data nominal dan ordinal dinyatakan dengan distribusi frekuensi dan data rasio disajikan sebagai rerata dan simpang baku. Uji normalitas dilakukan dengan uji Kolmogorof-Smirnov. Uji hipotesis untuk variabel bebas, variabel perancu dan variabel terikat yang bersifat kategorikal dengan uji $X^{2}$. Untuk variabel berskala rasio dengan distribusi normal dilakukan uji $t$ tidak berpasangan, sedangkan yang ber distribusi tidak normal dengan uji Mann Whitney. Uji beda proporsi kelompok berpasangan digunakan uji Mc.Nemar. Nilai $p$ dianggap bermakna bila $<0,05$. Besar risiko dinyatakan dengan nilai odd ratio (OR), dinyatakan sebagai faktor risiko bila OR $>1$ dengan confidence interval $(\mathrm{Cl})>1$. Analisis multivariat untuk mengetahui interaksi antar variabel bebas dan variabel perancu terhadap variabel terikat, dilakukan dengan uji Chi-Square, kemudian dikaji dengan regresi logistik multivariat dan uji stratifikasi menggunakan uji Mantel-Haenszel (19).

\section{HASIL}

Telah diteliti 94 subjek penelitian terdiri 47 kelompok kasus dan 47 kelompok kontrol. Karakteristik subjek, meliputi umur, jenis kelamin, berat dan panjang lahir, masa gestasi, ketuban pecah dini dan cara lahir pada kedua kelompok tidak berbeda bermakna $(p>0,05)$, begitu pula karakteristik pada orang tua (ibu dan ayah) meliputi pendidikan, pekerjaan dan status sosial-ekonomi pada kedua kelompok tidak berbeda bermakna $(p>0,05)$.

Tabel 1 menunjukkan, rerata kadar ke 3 antioksidan pada kelompok kasus (GPx 69,2 $\pm 30,82$, vitamin C 5,3 $\pm 1,85$, vitamin $E 17,5 \pm 0,86)$ lebih rendah bermakna dibanding kelompok kontrol (GPx 86,3 $\pm 29,24 ; p=0,0001$, vitamin C $7,3 \pm 3,97 ; p=0,004$, vitamin $\mathrm{E} 18,5 \pm 1,04 ; p=0,0001)$.

Tabel 1. Rerata kadar antioksidan (GPx, vitamin C, vitamin E)

\begin{tabular}{lccc}
\hline \multirow{2}{*}{$\begin{array}{c}\text { Antioksidan dan } \\
\text { Oxidan }\end{array}$} & \multicolumn{2}{c}{ Kelompok } & \multirow{2}{*}{$\boldsymbol{p}^{*}$} \\
\cline { 2 - 3 } & $\begin{array}{c}\text { Kasus } \\
\text { Mean } \pm \text { SB }\end{array}$ & $\begin{array}{c}\text { Kontrol } \\
\text { Mean } \pm \text { SB }\end{array}$ & \\
\hline GPx $(\mu / \mathrm{gHb})$ & $69,2 \pm 30,82$ & $86,3 \pm 29,24$ & 0,0001 \\
Vitamin C $(\mu \mathrm{g} / \mathrm{mL})$ & $5,3 \pm 1,85$ & $7,3 \pm 3,97$ & 0,004 \\
Vitamin E $(\mu \mathrm{g} / \mathrm{mL})$ & $17,5 \pm 0,86$ & $18,5 \pm 1,04$ & 0,0001 \\
MDA $(\mathrm{ng} / \mathrm{dL})$ & $5,3 \pm 2,06$ & $3,3 \pm 1,27$ & 0,0001 \\
\hline *Uji Mann- Whitney & & &
\end{tabular}

Analisis bivariat (Tabel 2) menunjukkan hubungan antara variabel bebas dengan variabel terikat. Hasil menunjukkan bahwa kadar antioksidan yang rendah (GPx $<75 \mu / \mathrm{gHb}$, vitamin $\mathrm{C}<7 \mu \mathrm{g} / \mathrm{mL}$, vitamin $\mathrm{E}<17,8 \mu \mathrm{g} / \mathrm{mL}$ ), merupakan faktor risiko terjadinya hemolisis pada neonatus sepsis, berturut-turut $(\mathrm{OR}=6,2 ; 95 \% \mathrm{Cl}=2,5-15,1$; $p=0,0001 ; \mathrm{OR}=2,4 ; 95 \% \mathrm{Cl}=1,04-5,50 ; p=0,039 ; \mathrm{OR}=3,42$; $95 \% \mathrm{Cl}=1,47-7,98 ; p=0,007)$.

Tabel 2. Uji hubungan antara kadar antioksidan dengan kejadian hemolisis

\begin{tabular}{lcccc}
\hline \multirow{2}{*}{ Antioksidan } & \multicolumn{2}{c}{ Kelompok } & \multirow{2}{*}{$P^{*}$} & OR (95\% CI) \\
\cline { 2 - 3 } & Kasus & Control & & \\
\hline $\begin{array}{l}\text { Kadar GPx } \\
<75 \mu / \mathrm{gHb}\end{array}$ & $33(70,2 \%)$ & $13(27,7 \%)$ & 0,0001 & $6,2(2,5-15,1)$ \\
$\geq 75 \mu / \mathrm{gHb}$ & $14(29,8 \%)$ & $34(72,3 \%)$ & & \\
& & & & \\
Kadar Vitamin C & & & & \\
$<7 \mu \mathrm{g} / \mathrm{Ml}$ & $31(33,0 \%)$ & $21(22,3 \%)$ & 0,039 & $2,4(1,04-5,50)$ \\
$\geq 7 \mu \mathrm{g} / \mathrm{mL}$ & $16(17,0 \%)$ & $26(27,7 \%)$ & & \\
$\begin{array}{l}\text { Kadar Vitamin E } \\
<17,8 \mu \mathrm{g} / \mathrm{mL}\end{array}$ & $30(63,8 \%)$ & $16(34,0 \%)$ & 0,007 & $3,42(1,47-7,98)$ \\
$\geq 17,8 \mu \mathrm{g} / \mathrm{mL}$ & $17(36,2 \%)$ & $31(66,0 \%)$ & & \\
\hline
\end{tabular}

$\mathrm{Uji} X^{2}$

Selanjutnya dilakukan uji regresi logistik multivariat dari semua variable yang terbukti berhubungan berdasarkan uji Chi-square. Hasil uji menunjukkan kadar GPx rendah $(<$ $75 \mu / \mathrm{gHb})$, kadar vitamin $\mathrm{E}$ rendah $(<17,8 \mu \mathrm{g} / \mathrm{mL})$ secara simultan dengan memperhatikan faktor antioksidan lain, merupakan prediktor signifikan terjadinya hemolisis. Kadar vitamin $\mathrm{C}$ rendah $(<7 \mu \mathrm{g} / \mathrm{mL})$ dengan memperhitungkan kadar GPx dan vitamin E, walau tidak bermakna namun karena $95 \% \mathrm{Cl}$ mendekati 1, maka cenderung merupakan faktor risiko terjadinya hemolisis.

Kuman Esherichia coli, penghasil hemolisin,dalam penelitian ini ditemukan pada 7 neonatus kelompok kasus dan 4 neonatus kelompok kontrol. Meskipun demikian semua hasil kultur darah tidak memperlihatkan adanya enzim hemolisin. 
Tabel 3. Hasil uji regresi logistik kadar antioksidan dan kejadian Hemolisis

\begin{tabular}{lccccc}
\hline \multicolumn{1}{c}{ Variabel } & B & S.E. & Wald & OR $(95 \%$ CI $)$ & Nilai- $p$ \\
\hline $\begin{array}{l}\text { Kadar GPx } \\
(<75 \mu / \mathrm{gHb})\end{array}$ & 1,814 & 0,487 & 13,896 & $6,14(2,36-15,92)$ & 0,0001 \\
$\begin{array}{l}\text { Kadar vit. C } \\
(<7 \mu \mathrm{g} / \mathrm{mL})\end{array}$ & 0,875 & 0,490 & 3,193 & $2,40(0,92-6,27)$ & 0,074 \\
$\begin{array}{l}\text { Kadar vit. E } \\
(<17,8 \mu \mathrm{g} / \mathrm{mL})\end{array}$ & 1,136 & 0,483 & 5,53 & $3,12(1,21-8,03)$ & 0,019 \\
& & & & & \\
\end{tabular}

\section{DISKUSI}

Peningkatan aktivitas antioksidan merupakan respon kompensasi terhadap adanya stress oksidatif. Glutathion peroksidase, vitamin E dan vitamin C dibantu oleh NADPH yang diproduksi G6PD, merupakan jaringan antioksidan untuk melawan stres oksidatif melalui peroksidasi lipid sehingga menjaga keutuhan membran eritrosit, mencegah hemolisis $(4,5)$.

Hasil penelitian menunjukkan, rerata kadar ke 3 antioksidan (GPx, vitamin C, vitamin E) pada kelompok kasus lebih rendah bermakna dibanding ke 3 antioksidan pada kelompok kontrol. Razzak dkk, melaporkan pada BCB dengan hiperbilirubinemia, kadar vitamin $C$ dan vitamin $\mathrm{E}$ lebih rendah bermakna dibanding $B C B$ yang tidak hiperbilirubinemia (20). Strachan dkk, melaporkan pada pasien kritis diantaranya sepsis berat, kadar selenium sebagai komponen integral GPx menurun selama periode stres oksidatif dan suplementasi selenium meningkatkan redistibusi ke endotel sehingga mencegah cedera sel (21). Penurunan antioksidan yang saling berinteraksi ini menunjukkan gagalnya peningkatan kadar antioksidan sebagai kompensasi pertahanan melawan stres oksidatif sehingga terjadihemolisis.

Peroksidasi lipid terjadi akibat pembentukan oksidan kuat melebihi kapasitas pertahanan antioksidan sehingga terjadi stres oksifatif, mengakibatkan putusnya rantai asam lemak menjadi berbagai senyawa toksik antara lain berbagai macam aldehid seperti malondialdehid (MDA) yang menyebabkan kerusakan parah membran sel berupa peningkatan permiabilitas membran hingga lisis sel. Malondialdehid digunakan sebagai biomarker biologis peroksidasi lipid untuk menilai stres oksidatif (3). Proses hemolisis merupakan petunjuk peningkatan stres oksidatif, juga meningkatnya kadar bilirubin (3). Bila dikaji, hasil penelitian menunjukkan rerata kadar oksidan (MDA) kelompok kasus lebih tinggi bermakna dibanding kelompok kontrol. Kapoor dkk melaporkan adanya peningkatan kadar MDA serum pada neonatus sepsis dan menyatakan bahwa kadar MDA neonatus sepsis lebih tinggi secara bermakna dibanding neonatus tanpa sepsis (22). Hal ini sejalan dengan peningkatan kadar bilirubin indirek sebagai petunjuk adanya hemolisis bahwa kadar bilirubin indirek pada kelompok kasus lebih tinggi

\section{DAFTAR KEPUSTAKAAN}

1. Haque KN. Definition of Blood Stream Infection in the Newborn. Pediatric Critical Care Medicine. 2005; 6(3): bermakna dibanding kelompok kontrol.

Analisis bivariat menunjukkan bahwa kadar antioksidan yang rendah $(\mathrm{GPx}<75 \mu / \mathrm{gHb}$, vitamin $\mathrm{C}<7 \mu \mathrm{g} / \mathrm{mL}$, vitamin $\mathrm{E}<17,8 \mu \mathrm{g} / \mathrm{mL})$, merupakan faktor risiko terjadinya hemolisis pada neonatus sepsis. Mohan dkk melaporkan, bahwa produksi radikal bebas oksigen yang lebih besar ditunjukkan oleh peningkatan kadar MDA sedangkan penurunan kadar GSH, vitamin C, vitamin E dan aktivitas katalase, menyokong adanya stres oksidatif pada pasien ikterus. Peningkatan aktivitas antioksidan enzim adalah kompensasi terhadap respon peningkatan stres oksidatif. Penurunan konsentrasi glutation dan antioksidan vitamin mensuport hipotesis bahwa ikterus neonatal adalah faktor penyebab penting dalam patogenesis peroksidasi lipid. Data ini menunjukkan kegagalan dalam mekanisme pertahanan antioksidan sehingga terjadi hemolisis (5).

Uji regresi logistik multivariat terhadap variabel bebas, terlihat: kadar GPx rendah $(<75 \mu / \mathrm{gHb})$, kadar vitamin $\mathrm{E}$ rendah $(<17,8 \mu \mathrm{g} / \mathrm{mL})$ dengan memperhatikan interaksi antioksidan lain merupakan prediktor signifikan terjadinya hemolisis. Sepsis, menghasilkan SOR sehingga terjadi stres oksidatif yang ditandai dengan meningkatnya produk peroksidasi lipid yaitu MDA dan respons mekanisme pertahanan antioksidan (GPx, vitamin C, vitamin E). Penurunan kadar antioksidan menunjukkan gagalnya mekanisme pertahanan terhadap stres oksidatif. Nielsen, melaporkan adanya peningkatan thiobarbituric acid (TBA) dan penurunan antioksidan pada syok septik (23). Adanya penurunan $\alpha$ tokoferol plasma yang disertai peningkatan kadar TBARS pada pasien kritis dibandingkan dengan kontrol yang mengindikasikan terjadinya peningkatan peroksidasi lipid (24).

Enzim hemolisin pada penelitian ini tidak didapati, sehingga hemolisin belum dapat dibuktikan sebagai faktor risiko kejadian hemolisis pada neonatus sepsis. Hal ini sangat mungkin karena tidak seluruh tipe $E$. coli dapat menghasilkan hemolisin, hanya serotipe yang bersifat invasif memiliki kemampuan untuk memproduksi hemolisin (14).

Pengukuran kadar MDA (oksidan) tidak menggunakan metode High Performance Liquid Chromatography (HPLC) karena dengan metode ini dapat meningkatkan spesifitas pada pemeriksaan kadar MDA (23). Pengukuran kadar MDA penelitian ini, mengukur TBARS dengan spektofotometri sehingga seluruh senyawa aldehid yang lain seperti etana $(\mathrm{C} 2 \mathrm{H} 6)$ dan pentane $(\mathrm{C} 5 \mathrm{H} 12)$ ikut terukur (25). Malondialdehid merupakan produk akhir peroksidasi lipid yang paling banyak ditemui, digunakan sebagai biomarker biologis peroksidasi lipid untuk menilai stres oksifatif (3). Aktivasi komplemen tidak diteliti sehingga tidak dapat diketahui besarnya pengaruh terhadap kejadian hemolisis pada neonatus sepsis.

Penelitian ini membuktikan hubungan antara kadar antioksidan dengan kejadian hemolisis. Kadar antioksidan yang rendah merupakan faktor risiko terjadinya hemolisis pada neonates sepsis.

45-49.

2. Alamsyah E. Analisis Epidemiologi Upaya Kesehatan Maternal Neonatal di Indonesia dalam Pencapaian 
Target Millenium Development Goals (MDGs) 2015. Perinasia. 2010; 1: 1-4.

3. Dalle-Donne I, Rossi R, Colombo R, Gustarini D, and Milzano A. Biomarkers of Oxidative Damage in Human Disease. Clinical Chemistry. 2006; 52(4):601-623.

4. Bender DA. Micronutrients: Vitamins \& Minerals. In: Harper (Ed). Illustrated Biochemistry 28th edition. Philadelphia: McGraw Hill; 2009; p. 467-481.

5. Mohan SK and Priya V. Status of Lipid Peroxidation, Glutathione, Ascorbic Acid, Vitamin E and Antioxidant Enzymes in Neonatal Jaundice Patients. Journal of Clinical and Diagnostic Research. 2008; 3: 827-832.

6. Wilson JX. Mechanism of Action of Vitamin C in Sepsis: Ascorbate Modulates Redox Signaling in Endothelium. International Union of Biochemistry and Molecular Biology. 2009; 35(1): 5-13.

7. Karim R and Mannan MA. $\alpha$-Tocopherol Reduces Oxidative Stress in Perinatal Asphyxia. Bangladesh Journal of Pharmacol. 2006; 1: 5-9.

8. Gill $\mathrm{H}$ and Walker G. Selenium: Immune Function and Resistence to Viral Infections. Nutrition \& Dietetics. 2008; 65(3): 41-47.

9. Segel GB. Hemolytic Anemia. In: Kliegman RM (Ed). Nelson Text Book of Pediatrics 19th edition. Philadelphia: Saunders; 2011; p. 1659-1682.

10. Ambalavanan $\mathrm{N}$ dan Carlo WA. Jaundice and Hyperbilirubinemia in the Newborn. In: Kliegman RM (Ed). Nelson Textbook of Pediatrics 19 edition. Philadelphia:Saunders; 2011; p. 603-612.

11. Gomella TL. Hyperbilirubinemia Indirect (Unconjugated Hyperbilirubinemia). In: Gomella TL (Ed). Neonatology 6th edition. New York: Mc Graw Hill; 2009; p. 293-301.

12. Lewis DB dan Wilson CB. Developmental Immunology and Role of Host Defenses in Fetal and Neonatal Susceptibility to Infection. In: Remington JS, Klein JO, Wilson CB, Nizet V, dan Maldonado YA (Ed). Infectious Diseases of the Fetus and Newborn Infant 7th edition. Philadelphia: Saunders; 2011; p. 81-172.

13. Murphy K, Travers P, dan Walport M. Allergy and Hypersensitivity. In: Janeway (Ed). Immunobiology7th edition. New York: Garland Science; 2008; hal. 555590.
14. Bauman R. Innate Immunity. In: Bauman R (Ed). Microbiology with Diseases by Taxonomy 2nd edition. New York: Pearson; 2007; p. 437-457.

15. Budhi K. Kejadian Hemolisis pada Neonatus Sepsis di PBRT RSDK Tahun 2006. Penelitian Pendahuluan. Unpublished.

16. Gordis L. Case Control and Cross-Sectional Studies. Baltimore: Saunders; 2009; p. 56-140.

17. Budhi K. Harga Normal Kadar MDA, GPx, Vitamin C, Vitamin E dan Hematokrit pada Bayi Sehat Bangsa Indonesia. Penelitian Pendahuluan. Unpublished.

18. Altman DG. Practical Statistics for Medical Research. Edisi 1. London: Chapman Hall; 1991.

19. Downson B dan Robert G. Research Questions About Two Separate or Independents Groups. In: Downson $B$, dan Robert G (Ed). Trapp Basic \& Clinical Biostatistics Edisi 4. Boston: McGraw Hill; 2004; p. 134-158.

20. Razzak KK, Nusier MK, Obediat AD, and Salim AM. Antioxidant Vitamins and Hyperbilirubinemia in Neonates. German Medical Science. 2007; 5: Doc03

21. Strachan S and Wyncoll D. Selenium in Critically III Patients. The Intensive Care Society. 2009; 10(1): 3843.

22. Kapoor K, Basu S, Das BK, and Bhatia BD. Lipid Peroxidation and Antioxidants in Neonatal Septicemia. Journal of Tropical Pediatrics. 2006; 52(5): 372-375.

23. Nielsen F, Mikkelsen BB, Nielseb JB, Andersen HR, and Grandjean P. Plasma Malondialdehyde as Biomarker Oxidative Stress: Reference Interval and Effects of Life Style Factors. Clinical Chemistry. 1997; 43(7): 12091214.

24. Donald J, Galley HF, and Webster NR. Oxidative Stress and Gene Expression in Sepsis. British Journal of Anaesthesia. 2003; 90(2): 221-232.

25. Yiqit S, Yurdakok M, Kilinc K, Oran O, Erdem G, and Tekinalp G. Serum Malondialdehyde Concentration as a Measure of Oxygen Free Radical Damage in Preterm Infants. The Turkish Journal of Pediatrics. 1998; 40(2): 177-183. 